\title{
Ekim sıklığının buğday (Triticum sp.) genotiplerinin verim ve bazı kalite özelliklerine etkisi
}

\author{
Effects of seeding rates on yield and some quality traits of wheat (Triticum sp.) genotypes
}

\author{
Mehmet ATAK $^{1 \mathcal{P}}$ (D) , Özlem KISA ${ }^{2}$ id , ibrahim ATIŞ ${ }^{1}$ \\ ${ }^{1}$ Hatay Mustafa Kemal University, Faculty of Agriculture, Department of Field Crops, Antakya-Hatay, Turkey. \\ ${ }^{2}$ Hatay Mustafa Kemal University, Graduate School of Natural and Applied Sciences, Department of Field Crops, Antakya-Hatay, \\ Turkey.
}

MAKALE BILGISI / ARTICLE INFO

Makale tarihçesi / Article history:

DOI: $10.37908 / \mathrm{mkutbd} .910456$

Geliş tarihi /Received:12.04.2021

Kabul tarihi/Accepted:24.05.2021

\section{Keywords:}

Wheat, wheat landraces, seeding rate, yield and quality.

\footnotetext{
Corresponding author: Mehmet ATAK

$\triangle:$ matak@mku.edu.tr
}

\section{ÖZET / A B S TR A C T}

Atıf / Citation: Atak M, Kısa Ö, Atış i (2021) Ekim sıklığının buğday (Triticum sp.) genotiplerinin verim ve bazı kalite özelliklerine etkisi. MKU. Tar. Bil. Derg. 26(2) : 387-398. DOI: 10.37908/mkutbd.910456

\section{GiRiş}

Buğday, insan beslenmesinde kullanılan tahıllar arasında dünyada ekiliş alanı (215.9 milyon ha) bakımından 1., üretim miktarı (756 milyon ton) bakımından ise mısırdan sonra 2. sırada yer almaktadır (Anonymous, 2020). Ülkemizde ise son verilere göre 20.5 milyon ton üretim miktarı ve 6.92 milyon ha'lık ekim alanı ile ilk sırada yer almaktadır (Anonim, 2020). Tanesinin beslenme yönünden dengeli ve yararlı besin içermesi, taşıma, saklama ve işlenmesindeki kolaylıklar ve geniş adaptasyon yetenekleri nedeniyle günümüzde birçok ülkenin temel kalori kaynağı durumundadır (Shewry, 2009; Anonymous,2020). Ülkemizde ekonomik yönden, tarla tarımı ve sosyal-kültürel açıdan stratejik bir öneme sahip olan buğdayın, artan nüfusa paralel olarak sürdürülebilir bir şekilde üretiminim artırılması için tüm dünya ülkelerinde olduğu gibi ülkemizde de çalışmalar 
hızla devam etmektedir. Buğday, buğday ürünleri ve ekmek geçmişte olduğu gibi günümüzde de Türk insanının en temel besin kaynaklarından biri durumundadır. Ülkemizde ekmek ve diğer buğday ürünleri dikkate alındığında kişi başı yıllık ortalama buğday tüketimi 200 kg'ın üzerindedir ve bu kullanım miktarı ile ülkemiz dünyada ilk sıralarda yer almaktadır (Morgounov ve ark., 2016). Buğday taşıdığı büyük değere bağlı olarak saygı duyulan, kutsal sayılan bir üründür. Ülkemiz, 20'den fazla yabani buğday ile buğday akraba türlerine ve 600 'den fazla ıslah edilmiş buğday çeşidine ev sahipliği yapmaktadır (Anonim, 2020).

Modern buğday ıslah çeşitlerinin yanında bazı yörelerde yetiştirilen yerel buğday çeşitleri (köy çeşitleri) yüzyıllar boyunca doğal seleksiyonlarla varlıklarını devam ettiren, geniş adaptasyon yeteneğine sahip, tane kaliteleri yüksek, çevresel stres şartlarına dayanıklı genetik kaynaklardır (Jaradat ve ark., 2013). Geleneksel yöntemlerin terk edilmesi, erozyon, kırsal nüfusun yaşlanması, yerel insan popülasyonlarının göç etmesi ve son olarak ta çevresel bozulmalar sonucu birçok yerel buğday köy çeşidi yok olmuştur. Yerel (köy çeşitlerinin) modern çeşitlerle rekabet edememesi nedeniyle bu buğdayların ekim alanları da giderek azalmıştır (Anonim, 2016). Bu çeşitler buğday ıslahı için bulunmaz birer hazine niteliğindedirler (Karagöz ve Zencirci, 2015; Anonim, 2016; Atak, 2017) ve bunların yetiştirici elinde korunması, üretiminin artırılması ve tanıtılması büyük önem taşımaktadır (Anonim, 2016; Atak, 2017). Bu çeşitlerin ücra yörelerde, engebeli yamaç ve kıraç arazilerde üretimleri yapılmakla birlikte birçoğunun yerini günümüzde modern buğday ıslah çeşitleri almıştır. Hızla artan nüfusun, parçalanan ve verimliliği azalan tarım alanlarından elde edilen üretimle yeterli ve dengeli beslenmesi, her geçen gün daha da zorlaşmaktadır. Bu nedenle artan temel besin ihtiyaçlarının karşılanmasında, bölge ekolojik koşullarına iyi uyum gösteren, verim ve kalite özellikleri iyi olan yeni genotiplerin belirlenmesi ve ıslah edilmesi büyük önem taşımaktadır. Bununla birlikte bölge şartlarına uzun yıllardır uyum sağlamış yerel çeşitlerin ıslah materyali ve doğrudan kullanım özelliklerinden dolayı korunması üretiminin artırılması da gerekmektedir. Buğday köy çeşitleri ve geliştirilen eski çeşitler yabani buğdaylar ile modern buğday çeşitleri arasında bağ konumundadır. Yapılan ıslah çalışmalarında bu çeşitlerden yararlanılmaktadır (Kün, 1996; Anonim, 2016).

Buğdayda genel olarak birim alana atılacak tohum miktarı, tohumluğun genetik, fiziksel ve biyolojik değerlerine bağlı olarak 450-650 tohum $\mathrm{m}^{-2}$ olarak bildirilmektedir (Kün, 1996). Buğdayda uygun ekim sıklığı konusunda yapılmış birçok çalışma bulunmasına karşın, yerel çeşitlerde uygun ekim sıklı̆ı̆ konusunda ülkemizde yeterli çalışma bulunmamaktadır. Adana, Hatay ve iç̧el illerini kapsayan Çukurova bölgesi ekolojik faktörlerin uygunluğu nedeniyle ülkemizin önemli buğday üretim alanlarıdır. Son yıllarda, Doğu-Akdeniz (Adana-Hatay) bölgesinde modern buğday ıslah çeşitlerinin yetiştirilmesiyle bölgenin genetik değerleri olan yerel köy çeşitleri yok olma tehlikesi ile karşı karşıya kalmıştır. Bu çeşitlerin üretimini sürekli kılmak, yok olmalarını önlemek amacıyla bu genotiplerin tanıtılması ve üretiminin desteklenmesinin yanında üretimi artırıcı veya etkileyen agronomik çalışmalarında yapılarak sonuçlarının üreticilere ulaştırılması gerekmektedir.

Bu çalışmanın amacı: Ekim sıklığının Hatay ekolojik koşullarında yetiştirilen bazı yerel çeşit ve buğday ıslah çeşitlerinin verim ve bazı kalite özelliklerine etkisini belirlenmektir.

\section{MATERYAL ve YÖNTEM}

\section{Materyal}

Çalışmada Araştırmada; 2 adet makarnalık köy (yerel) çeşidi (Karakılçık ve Havrani), 2 adet makarnalık buğday çeşidi (Gediz-75 ve Fırat-93), 1 adet ekmeklik köy (yerel) çeşidi (Fransız) ve 1 adet ekmeklik buğday çeşidi (Masaccio) materyal olarak kullanılmıştır. Gediz-75 ve Fırat-93 Akdeniz ve kıyı bölgeler için önerilen tescilli yerli makarnalık çeşitlerdir. Karakılçık ve Havrani ise bölgenin yerel makarnalık buğday köy çeşitleri, Fransız yerel ekmeklik buğday köy çeşidi ve Masaccio ekmeklik buğday çeşidi ise Progen Tohum A.Ş tarafından tescil ettirilmiş olup, Çukurova, Hatay, Kahramanmaraş, Güneydoğu Anadolu Bölgesi, Ege Bölgesi, Karadeniz ve Trakya Bölgeleri için önerilmektedir

\section{Araştırma yerinin iklim ve toprak özellikleri}

Araştırmalar, 2016-2018 bitki yetiştirme dönemlerinde; Hatay-Kırıkhan ilçesi ( $36^{\circ} 44^{\prime}$ kuzey enlemi, $36^{\circ} 40^{\prime}$ doğu boylamı) çiftçi tarlasında yürütülmüştür. Araştırmanın yürütüldüğü alana ilişkin bazı iklim verileri Çizelge 1 ve Çizelge 2'de verilmiştir.

Araştırmanın yürütüldüğü 1.yıl, Kasım-2016-Mayıs 2017 arası dönemde ise deneme alanına düşen yağış miktarı $534 \mathrm{~mm}$ civarındadır. Denemenin 2. yılında (Ekim 2017Mayıs 2018) döneminde gerçekleşen toplam yağış miktarı $532.3 \mathrm{~mm}$ olduğu, bu değerin ise bölgenin uzun yıllar ortalama değerleri civarında olduğu görülmektedir (Çizelge 1). 
Çizelge 1. Araştırma alanına ilişkin toplam yağış verileri (mm) (Anonim, 2018)

Table 1. Total precipitation amount for the experimental area $(\mathrm{mm})$

\begin{tabular}{lcccccccccccccc}
\hline YII & \multicolumn{1}{c}{ Aylık Yağıs Miktarı $(\mathbf{m m})$} & \multicolumn{1}{c}{ Toplam } \\
\hline & $\mathbf{1}$ & $\mathbf{2}$ & $\mathbf{3}$ & $\mathbf{4}$ & $\mathbf{5}$ & $\mathbf{6}$ & $\mathbf{7}$ & $\mathbf{8}$ & $\mathbf{9}$ & $\mathbf{1 0}$ & $\mathbf{1 1}$ & $\mathbf{1 2}$ & \\
2016 & 111.2 & 42.8 & 63.4 & 7.8 & 37.6 & 5.6 & 4.4 & 2.6 & 15.1 & 8.7 & 34.1 & 179.1 & 512.1 \\
2017 & 144.1 & 1.2 & 107.0 & 47.4 & 20.6 & 1.4 & 0.0 & 0.0 & 0.0 & 3.1 & 51.8 & 31.9 & 408.5 \\
2018 & 143.0 & 85.4 & 11.6 & 20.0 & 11.8 & 16.4 & 0.0 & 0.0 & 0.0 & 38.6 & 87.0 & 90.0 & 503.8 \\
Uzun Yıllar & 110.0 & 95.0 & 77.0 & 54.0 & 26.0 & 10.0 & 1.0 & 2.0 & 8.0 & 43.0 & 60.0 & 98.0 & 584.0 \\
\hline
\end{tabular}

Çizelge 2. Araştırma alanına ilişkin sıcaklık verileri $\left({ }^{\circ} \mathrm{C}\right)($ Anonim, 2018)

Table 2. Temperature values for the experimental area $\left({ }^{\circ} \mathrm{C}\right)$

\begin{tabular}{lccccccccccccc} 
Yıl & \multicolumn{1}{c}{} & \multicolumn{1}{c}{ Aylık Yağış Miktarı $(\mathbf{m m})$} & \multicolumn{1}{c}{ Toplam } \\
\hline \multirow{2}{*}{2016} & $\mathbf{1}$ & $\mathbf{2}$ & $\mathbf{3}$ & $\mathbf{4}$ & $\mathbf{5}$ & $\mathbf{6}$ & $\mathbf{7}$ & $\mathbf{8}$ & $\mathbf{9}$ & $\mathbf{1 0}$ & $\mathbf{1 1}$ & $\mathbf{1 2}$ \\
2017 & 6.3 & 13.1 & 15.6 & 21.4 & 22.4 & 29.1 & 31.6 & 31.2 & 27.1 & 23.1 & 14.7 & 8.8 & 20.2 \\
2018 & 8.9 & 10.5 & 14.3 & 18.2 & 22.5 & 28.2 & 32.6 & 30.9 & 29.1 & 22.8 & 15.8 & 12.0 & 20.4 \\
Uzun YIllar & 9.1 & 11.6 & 15.8 & 19.2 & 23.8 & 26.5 & 28.7 & 29 & 27.2 & 21.4 & 14.2 & 9.4 & 19.7 \\
& 7.8 & 9.2 & 12.4 & 16.6 & 21.1 & 25.3 & 27.8 & 28.4 & 26.1 & 20.5 & 14.0 & 9.5 & 18.2 \\
\hline
\end{tabular}

Deneme yıllarında çok fazla göze çarpan ekstrem sıcaklık değerleri gözlenmediği görülmektedir. Sıcaklık değerleri uzun yıllar ortalama değerleri civarında gerçekleşmiştir. Denemenin yürütüldügü Ocak-Mayıs aylarındaki aylık ortalama sıcaklık değerleri ise uzun yıllar ortalamasından biraz yüksek olarak gerçekleşmiştir (Çizelge 2).

Araştırma alanına ait toprak örnekleri $0-30 \mathrm{~cm}$ derinlikten ekim öncesi alınmış ve MKÜ Teknoloji ve ARGE Uygulama ve Araştırma Merkezi (MARGEM) laboratuvarında toprak anali edilmiştir. Bu analize göre; araştırma alanının toprağının hafif alkalin yapıda, organik madde içeriği yönünden zayıf karakterde olduğu belirlenmiştir. Toprak tuzsuz, hafif alkali ve aşırı kireçli yapıdadır. Deneme alanı toprak tekstürü "killi toprak" olarak tanımlanmış olup, potasyum içeriği yüksek, fosfor ve azot yönünden zayıf olduğu saptanmıştır.

\section{Denemenin kurulması ve yürütülmesi}

Ekim sıklıkları; m²'de 450 (S1), 550 (S2) ve 650 (S3) adet canlı tohum olacak şekilde ayarlanmış ve $4 \mathrm{~m}$ boyundaki parsellere 5 sıra ve sıra arası mesafe $25 \mathrm{~cm}$ olacak şekilde elle ekim yapılmıştır. Denemeler; Tesadüf Blokları Bölünmüş Parseller Deneme Deseninde 3 tekerrürlü olarak kurulmuş, ana parsellere ekim sıklıkları ve alt parsellere ise çeşitler yerleştirilmiştir. Denemede taban gübresi olarak, $20 \mathrm{~kg} \mathrm{da}^{-1}$ hesabıyla DAP (18-46; N-P) gübresi, üst gübre olarak ise, $20 \mathrm{~kg} \mathrm{da}^{-1}$ Üre (\% 46) kullanılmıştır. Ekimler, 1. yıl 17 Kasım 2016 tarihinde, 2. yıl ise 19 Kasım 2017 tarihinde elle yapılmıştır. Denemede sulama yapılmamış olup, herhangi bir hastalık ve zararlı görülmediği için bir kimyasal mücadelede bulunulmamıştır Yabancı otlara karşı gerekli mücadele elle yapılmıştır. Parsellerde gerekli veriler aşağıda belirtildiği şekilde alınmış olup, hasat elle yapılmış olup, parsel patözü ile harman yapılmıştır.

\section{Verilerin elde edilmesi}

Araştırmada, başaklanma süresi (gün), bitki boyu (cm), başak uzunluğu (mm), başakta tane sayısı (adet başak ${ }^{-1}$ ), başakta tane ağırlığı (g başak $\left.{ }^{-1}\right)$, tane verimi $\left(\mathrm{kg} \mathrm{da}^{-1}\right)$, bin tane ağırlığı (g), hektolitre ağırlığı $(\mathrm{kg})$ incelenmiştir. Protein oranı (\%), öğütülmüş tanelerde Kjeldahl yöntemiyle belirlenirken, kuru gluten oranı (\%), Perten DA 7250 NIR analizörü cihazının cihaz okuma değeri olarak belirlenmiştir.

\section{Verilerin değerlendirilmesi}

Araştırmada elde edilen veriler Tesadüf Blokları Bölünmüş Parseller Deneme Desenine göre istatistik paket programı (Mstat-C) kullanılarak iki yıl birlikte varyans analizine tabi tutulmuştur. F-testi ile önemlilik kontrolleri, Duncan testi ile \% 5 seviyesinde farklılık gruplandırmaları yapılmıştır.

\section{BULGULAR ve TARTIŞMA}

Araştırmada elde edilen verilere uygulanan varyans analizi, başaklanma süresi üzerine her iki deneme faktörünün ve interaksiyonun etkisinin istatistiksel olarak önemli olduğunu göstermiştir (Çizelge 3 ). Araştırmada kullanılan buğday genotiplerinin başaklanma süresi 107.1 gün ile 119.9 gün arasında değişim göstermiştir. Bu sonuçlar en erkenci ve geççi çeşit arasında başaklanma süresi açısından 12 günlük bir farkı ortaya koymuştur. Massacio, 119.9 gün ile diğer çeşitlere göre önemli derecede geç başaklanmıştır. Kullanılan çeşitler arasında Gediz-75 diğer çeşitlere göre 
önemli derecede erken başaklanmıştır. Diğer çeşitler ise bu iki çeşidin arasında bir başaklanma süresine sahip olmuşlardır. Fırat-93 ve Havrani çeşitleri istatistiksel olarak benzer grupta yer alırken, diğer çeşitlerin her biri istatistiksel olarak farklı başaklanma sürelerine sahip olmuşlardır. Erkencilik iklim ve toprak özellikleri ile etkilenebilecek bir özellik olmakla birlikte, temelde çeşidin genetik özellikleri ile kontrol edilmektedir. Nitekim mevcut sonuçlar aynı koşullarda yetiştirilen genotiplerin başaklanma süresinin farklı olması bunu desteklemektedir. Deneme yıllarında ilkbahar aylarında görülen yağış farklııkları çeşitlerin farkı başaklanma sürelerine etkide bulunmuş olabir. Erkencilik, buğdayda istenen bir özellik olup, erken başaklanan genotiplerde başaklanma ile olgunlaşma arasındaki sürenin uzamasına bağlı olarak kuru madde birikimi ve verim artmaktadır. Ayrıca erkencilik, başaklanma sonrası yüksek sıcaklık, kuraklık ve kuru rüzgarların etkili olduğu alanlarda bitkiye bir avantaj sağlamaktadır (Menshawy., 2007). Bununla birlikte çok erkenci buğday çeşitleri bazı yıllarda geç ilkbahar donlarından zarar görebilmektedir. Bitki sıklı̆ıının 450 tohum $\mathrm{m}^{-2}$ den 550 ve 650 tohum $\mathrm{m}^{-2}$ ye çıkması başaklanma süresinde önemli bir kısalmaya neden olmuştur (Çizelge 3). 450 tohum $\mathrm{m}^{-2}$ sıklıkta 113.8 gün olarak tespit edilen başaklanma süresi metrekarede 550 ve 650 tohum sıklıkları için sırasıyla 111.9 ve 112.1 gün olarak belirlenmiş ve bu iki sıklık için belirlenen değerler istatistiksel olarak farksız olmuştur. Benzer şekilde bazı diğer araştırıcılar da buğdayda artan bitki sıklığına bağlı olarak başaklanma süresinin kısaldığını bildirmişlerdir (Geleta ve ark., 2002; Pala, 2016). Bu durum, artan sıklıkla birlikte bitkiler arasında artan kaynak rekabetine bağlı olarak bitkilerin hızlı olgunlaşma eğiliminde olmaları ile açıklanabilir.

Varyans analiz sonuçları bitki sıklığı $\times$ genotip interaksiyonunun da başaklanama süresi üzerine etkisinin önemli olduğunu göstermiştir (Çizelge 3). Bu genotiplerin bitki sıklıklarındaki değişime tepkisinin farklı olduğunu göstermektedir. Karakılçık, Fırat-93 ve Masscacio genotiplerinin başaklanma süresi sıklığın metrekarede 450 tohumdan 550 ve 650 tohum m-2 sıklığa çıkmasıyla önemli derecede kısalırken, Gediz-75, Fransız ve Havrani genotiplerinin başaklanma süresi bitki sıklığındaki değişimden etkilenmemiştir (Şekil 1). Bu durum çeşitlerin doğal kaynak kullanım yeteneklerinin ve çevre koşullarındaki değişime tepkilerinin farklı olması ile ilişkilendirilebilir. Bununla birlikte genotiplerin başaklanma süresi ile makarnalık veya ekmeklik olması, köy tipi veya modern ıslah çeşidi olması arasında doğrusal bir iliş̧i gözlenmemiştir.

Kullanılan genotiplerin bitki boyları birbirinden önemli farklılık göstermiştir. Genotiplere bağlı olarak bitki boyları $96.3 \mathrm{~cm}$ ile $114.9 \mathrm{~cm}$ arasında değişim göstermiş, Massacio en kısa boylu, Gediz-75 ise en uzun boylu genotipler olarak tespit edilmiştir (Çizelge 3). Massacio genotipinde belirlenen bitki boyu değeri Karakılçık, Gediz-75 ve Fransız genotiplerinden önemli derecede kısa bulunurken diğer genotiplerle istatistiksel olarak benzer bulunmuştur.

Çizelge 3. Araştırmada iki yıllık ortalama olarak belirlenen başaklanma süresi, bitki boyu, başak uzunluğu, başakçık sayısı ve başakta tane ağılığı değerlerinin genotip ve ekim sıklığına bağlı değişimi ve önem seviyeleri

Table 3. The variation and significance levels of heading time, plant height, spike length, number of spikelets and grain weight per spike determined as two-year average in the study depending on the genotype and seeding rates

\begin{tabular}{|c|c|c|c|c|c|}
\hline & $\begin{array}{l}\text { Başaklanma } \\
\text { Süresi (gün) }\end{array}$ & Bitki Boyu (cm) & $\begin{array}{l}\text { Başak Uzunluğu } \\
(\mathrm{mm})\end{array}$ & $\begin{array}{l}\text { Başakta Tane } \\
\text { Sayısı (adet) }\end{array}$ & $\begin{array}{l}\text { Başakta Tane } \\
\text { Ağırlığı (g) }\end{array}$ \\
\hline \multicolumn{6}{|l|}{ Genotipler } \\
\hline Karakılçık & $115.3^{b+}$ & $107.6^{b}$ & $80.8^{b}$ & $40.7^{b}$ & $1.97^{c}$ \\
\hline Fırat-93 & $110.0^{d}$ & $102.5^{b c}$ & $71.7^{c}$ & $45.8^{a}$ & $2.61^{a}$ \\
\hline Gediz-75 & $107.1^{\mathrm{e}}$ & $114.9^{a}$ & $83.7^{a b}$ & $40.9^{b}$ & $2.28^{b}$ \\
\hline Havrani & $109.3^{d}$ & $102.9^{b c}$ & $76.3^{b c}$ & $39.8^{b}$ & $2.24^{b}$ \\
\hline Fransız & $113.9^{c}$ & $109.4^{a b}$ & $90.8^{a}$ & $38.6^{b}$ & $1.99^{c}$ \\
\hline Massacio & $119.9^{a}$ & $96.3^{c}$ & $75.6^{b c}$ & $38.8^{b}$ & $1.83^{c}$ \\
\hline Önem seviyesi (G) & $* *$ & $* *$ & $* *$ & $* *$ & $* *$ \\
\hline \multicolumn{6}{|c|}{ Ekim Sıklıkları (tohum $\mathrm{m}^{-2}$ ) } \\
\hline 450 & $113.8^{a}$ & 107.2 & 81.5 & $42.1^{a}$ & 2.25 \\
\hline 550 & $111.9^{b}$ & 105.4 & 80.2 & $41.2^{\mathrm{a}}$ & 2.17 \\
\hline 650 & $112.1^{b}$ & 104.3 & 77.8 & $39.0^{b}$ & 2.04 \\
\hline Önem seviyesi (ES) & $* *$ & ns & ns & $*$ & Ns \\
\hline Önem seviyesi (ESXG) & $*$ & $\mathrm{~ns}$ & ns & $*$ & $* *$ \\
\hline
\end{tabular}

+) Aynı sütunda farklı harflerle gösterilen faktör ortalamaları birbirinden farklıdır $(\mathrm{P}<0.05)$;

*: \%5 hata sınırları içerisinde önemli; **: \%1 hata sınırları içerisinde önemli; ns: önemsiz. 


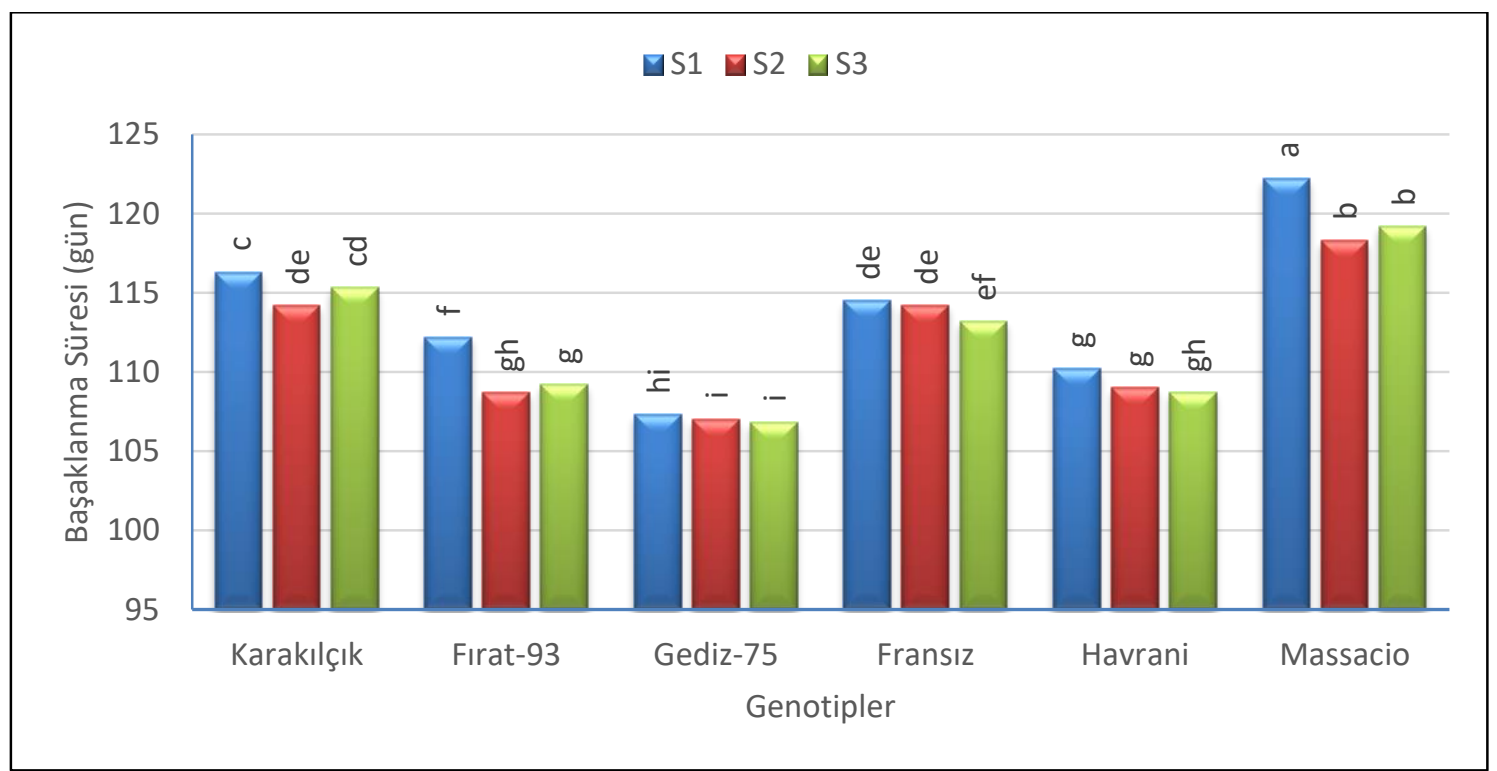

Şekil 1. Başaklanma süresinin ekim sıklı̆̆ı $\times$ genotip interaksiyonuna bağlı olarak değişimi

Figure 1. Variation of heading time depending on seeding rate $\times$ genotype interaction

En yüksek bitki boyu değerine sahip Gediz-75 ise Fransız dışındaki tüm genotiplerden istatistiksel olarak daha uzun bulunmuştur. Buğday genotiplerine bağlı olarak bitki boyunun değiştiği diğer araştırıcılar tarafından da bildirilmiştir (Mut ve ark., 2007; Kendal ve ark., 2012; Ulucan ve Atak, 2020). Bitki boyu çevre koşullarından yüksek oranda etkilenen bir özellik ise de bitkinin genotipik özelliklerinin kontrolü altındadır. Bu çalışmada genotipler arasındaki farklılıklar da bu durumu ortaya koymaktadır (Kendal ve ark., 2012). Ekim sıklıklarının bitki boyu üzerine etkisi ise önemsiz bulunmuştur (Çizelge 3). Bitki sıklığındaki artışa bağlı olarak bitki boyunda bir azalma eğilimi olmakla birlikte bu değişim istatistiksel olarak anlamlı bulunmamıştır. Bazı araştırıcılar, buğdayda artan bitki sıklığına bağlı olarak bitki boyunun arttığını bildirirken (Özer, 1997; Gençtan ve Sağlam 1987), bazı araştırıcılar, bitki sıklığının bitki boyunu önemli derecede etkilemediğini bildirmişlerdir (Kazan ve Doğan, 2005; Ulucan ve Atak, 2020). Bazı araştırma sonuçları buğdayda bitki boyunun çevre koşulları, özellikle yağış, yüksek sıcaklık ve bitki besin maddeleri mevcudiyeti ile genotipik özelliklere sıkı sıkıya bağlı olduğunu, bununla birlikte yetiştirme tekniklerinden de etkilenebileceğini işaret etmektedir (Atak ve Çiftçi, 2006; Mut ve ark., 2007). Bitki boyu özellikle buğdayda yatmaya dayanıklılık açısından önemli bir özellik olup, yatmaya karşı dayanıklııı açısından serin iklim tahıllarında $80-100 \mathrm{~cm}$ bitki boyunun yeterli olduğu bildirilmektedir (Kün, 1996).

Başak uzunluğu üzerine genotiplerin etkisi önemli bulunurken, bitki sıklıkları ve bitki sıklığı $\times$ genotip interaksiyonunun etkisi önemsiz bulunmuştur (Çizelge 3). Genotipler arasında başak uzunluğu $71.7 \mathrm{~mm}$ ile 90.8 $\mathrm{mm}$ arasında değişmiştir. Fransız genotipi, Gediz-75 dışındaki diğer tüm genotiplerden daha yüksek başak uzunluğu değerine sahip olmuştur. Fırat-93 en kısa boylu genotip olarak kaydedilirken, başak uzunluğu bakımından Havrani ve Massacio ile benzer grupta yer almıştır. Bulgularımızla uyumlu olarak bazı diğer araştırıcılarda buğday genotiplerinin başak boyunun birbirinden farklı olduğunu bildirmişlerdir (Özen ve Akman, 2015; Aydoğan ve Soylu, 2017). Başak uzunluğu genotipe bağlı bir özellik olup genellikle uzun başak boyuna sahip genotiplerin daha verimli oldukları bildirilmekte ve ıslah programlarında uzun başaklı genotiplerin seçilmesi önerilmektedir (Bilgin ve Korkut, 2005). Artan bitki sıklıkları, bir azalma eğilimine rağmen, başak uzunluğunda istatistiksel olarak önemli bir farklılık meydana getirmemiş, başak uzunlukları artan sıklıklara bağlı olarak sırasıyla, $81.5,80.2$ ve $77.8 \mathrm{~mm}$ olarak kaydedilmiştir. Dinç ve Erekul (2010) buğdayda başak boyunun bitki sıklıklarındaki artışla azaldığını ve bu artışın istatistiksel olarak önemli olduğunu bildirmiştir. Bu durum araştırııının daha düşük bitki sıklıklarını da araştırmaya dahil etmesi ile ilgili olabilir. Bununla birlikte, yetiştirme koşullarındaki iklimsel farklılıklar özellikle yağış ve sıcaklık değerleri de bu durumda etkili olabilir.

Başakta tane sayısı genotiplere bağı ılarak 38.6 ile 45.8 adet arasında değişmiştir (Çizelge 3). Fırat-93 genotipi diğer genotiplere göre istatistiksel olarak daha yüksek başakta tane sayısına sahip olmuştur. Diğer 6 genotip ise başakta tane sayısı bakımından benzer grupta yer almıştır. Genotiplere bağı ı olarak başakta tane sayısının farklılık gösterdiği diğer araştırıcılar tarafından da bildirilmiştir ve bu araştırmada belirlenen başakta tane 
sayısı değerleri literatürle uyumludur (Özen ve Akman, 2015; Aydoğan ve Soylu, 2017; Ulucan ve Atak, 2020). Başakta tane sayısı değerleri 450, 550 ve 650 tohum $\mathrm{m}^{-2}$ sıklıkları için sırasıyla $42.1,41.2$ ve 39.0 adet olarak belirlenmiştir (Çizelge 3). Bitki sıklığının 450 tohum $\mathrm{m}^{-2}$ den 550 tohum $\mathrm{m}^{-2 \prime}$ ye çıkması başakta tane sayısında önemli bir azalmaya neden olmamış, 650 tohum $\mathrm{m}^{-2}$ sıklıkta başakta tane sayısı önemli derecede azalmıştır. Benzer şekilde diğer araştırıcılarda başakta tane sayısının artan bitki sıklıklarına bağlı olarak azalma eğiliminde olduğunu bildirmişlerdir (Arısoy ve ark., 2005; Dinç ve Erekul, 2010; Pala, 2016).

Başakta tane sayısı bakımından genotiplerin bitki sıklıklarına tepkisinin farklı olması bitki sıklığı $\times$ genotip interaksiyonunun önemli çıkmasına neden olmuştur (Çizelge 3). Karakılçık, Fırat-93 ve Gediz-75 genotiplerinde artan sıklıklara bağı ılarak başakta tane sayısı azalma eğilimi gözlemlenirken, diğer genotiplerde önemli olmayan artış eğilimleri gözlemlenmiştir (Şekil 2). Araştırmada Karakılçık, Fırat-93 ve Gediz-75 genotiplerinin 450 tohum $\mathrm{m}^{-2}$ sıklıklarında daha yüksek başakta tane sayısı değerlerine sahip olduğu belirlenmiştir. Buğdayda başakta tane sayısının verimle ilişkili bir özellik olduğu ve ıslah çalışmalarında önemli bir seleksiyon kriteri olduğu bildirilmektedir (Aktaş, 2010).

Başakta tane ağırlığı bakımından genotipler arasındaki farklııklar ile bitki sıklığı $\times$ genotip interaksiyonu önemli bulunurken, bitki sıklığının etkisi önemsiz bulunmuştur. Genotipler arasında tane ağırlıkarı $1.83 \mathrm{~g}$ ile $2.61 \mathrm{~g}$ arasında değişim göstermiştir. Fırat-93 genotipi diğerlerinden istatistiksel olarak daha yüksek başakta tane ağılığı değerine sahip olmuştur (Çizelge 3). Bu durum Fırat-93'ün başakta tane sayısı bakımından da daha yüksek değere sahip olması ile ilişkili olabilir. Fırat93'ü Havrani ve Gediz-75 takip etmiş ve bu iki genotip istatistiksel olarak aynı grupta yer almıştır. Genel olarak bakıldığında, Karakılçık hariç, makarnalık buğday genotiplerinin ekmeklik buğday genotiplerine göre daha yüksek başakta tane ağıllığı değerlerine sahip olduğu söylenebilir. Başakta tane ağırlığı bakımından genotipler arasında önemli farklılıklar olduğu diğer araştırıcılar tarafından da bildirilmiştir (Sakin ve ark., 2004; Özen ve Akman, 2015). Artan bitki sıklıklarına bağlı olarak başakta tane ağırlığı değerleri sırasıyla $2.25 \mathrm{~g}, 2.17 \mathrm{~g}$ ve $2.04 \mathrm{~g}$ olarak belirlenmiş olup, azalma eğilimine rağmen, bu değişim istatistiksel olarak önemli bulunmamıştır. Arısoy ve ark. (2005) ve Pala (2016) ise artan sıklıklara bağıı olarak başakta tane ağırlıklarına bağlı olarak ortaya çıkan azalmanın önemli olduğunu bildirmişlerdir. Başakta tane ağırlığı bakımından çeşitlerin bitki sıklıklarına tepkisinin farklı olması bitki sıklığı $\times$ genotip interaksiyonunun önemli çıkmasına neden olmuştur. Tüm uygulamalar içerisinde 450 tohum $\mathrm{m}^{-2}$ sıklıkla ekilen Fırat-93 genotipi en yüksek başakta tane ağırlığı değerine sahip olmuştur (Şekil 3). Fırat-93 ve Gediz-75 genotiplerinin başakta tane ağılıkları artan sıklıklara bağlı olarak önemli derecede azalırken, diğer çeşitlerin başakta tane ağırlıkları bitki sıklıklarına bağı olarak önemli bir değişim göstermemiştir. Bu durum genotiplerin mevcut kaynaklardan yararlanma yeteneğinin ve çevre koşullarındaki değişime tepkilerinin farklı olduğunu göstermektedir.

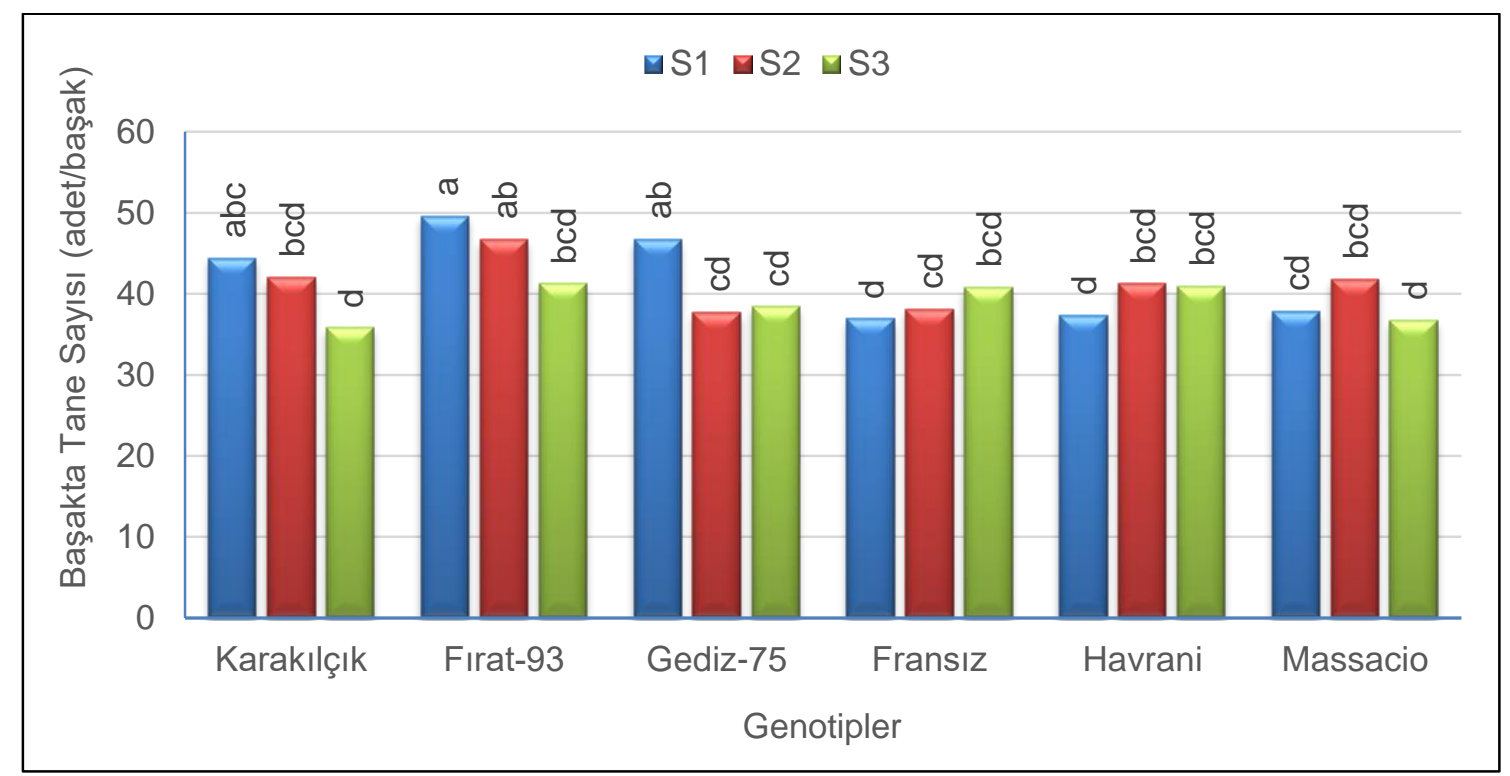

Şekil 2. Başakta tane sayısının ekim sıklığı $\times$ genotip interaksiyonuna bağlı olarak değişimi Figure 2. Variation of grain nunber per spike depending on sowing frequency $\times$ genotype interaction 


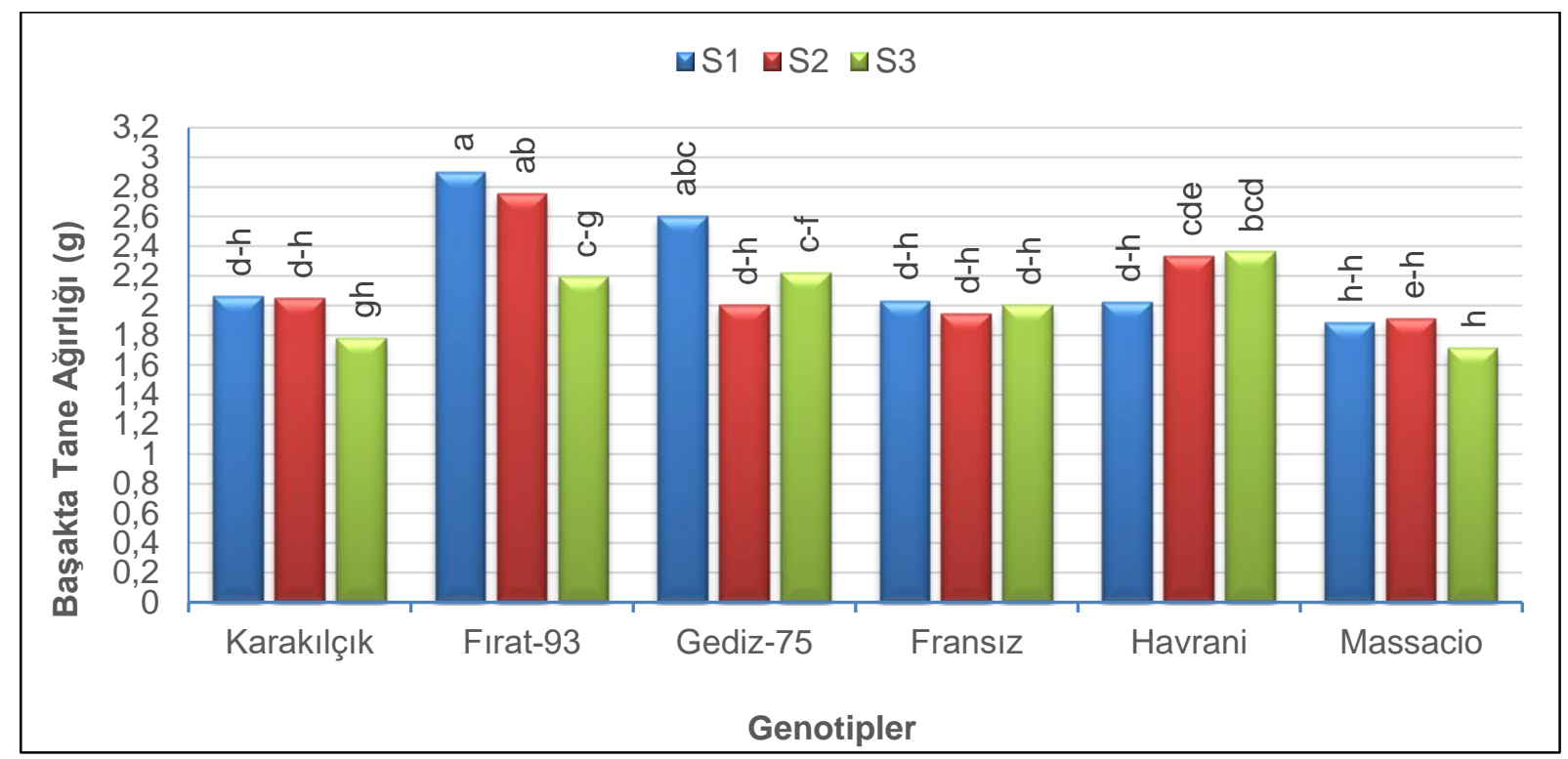

Şekil 3. Başakta tane ağılığının ekim sıklığı $\times$ genotip interaksiyonuna bağlı olarak değişimi

Figure 3. Variation of grain weight depending on sowing frequency $\times$ genotype interaction

Varyans analiz sonuçları her iki deneme faktörünün ve ikili interaksiyonun 1000 tane ağırlığı üzerindeki etkisinin önemli olduğunu göstermiştir (Çizelge 4). Havrani ve Fırat-93 genotipleri diğer genotiplerden daha yüksek 1000 tane ağırlığı değerine sahip olurken, Karakılçık en düşük 1000 tane ağırlığına sahip genotip olmuştur. Genel olarak bakıldığında, Karakılçık hariç, makarnalık genotiplerin 1000 tane ağırlığının ekmeklik genotiplerden daha yüksek olduğu söylenebilir. 1000 tane ağırlığı bakımından genotipler arasında önemli farklılıklar diğer bazı araştırıcılar tarafından da bildirilmiştir (Akgün ve ark., 2011; Kendal ve ark., 2012; Özen ve Akman, 2015; Sönmez ve Olgun; 2019). Bitki sıklıkları için 1000 tane değerleri 450, 550 ve 650 tohum m-2 sıklıkları için sırasıyla $45.9,44.8$ ve $42.8 \mathrm{~g}$ olarak belirlenmiştir (Çizelge 4). Bitki sıklığının 450 tohum m ${ }^{-2}$ ' den 550 tohum $\mathrm{m}^{-2 \prime}$ ye çıkması 1000 tane ağırlığında önemli bir azalmaya neden olmazken, 650 tohum $\mathrm{m}^{-2}$ sıklıkta 1000 tane ağırlığı önemli derecede azalmıştır. Bitki sıklığındaki artışa bağlı olarak 1000 tane ağılığının azaldığı yönündeki bulgularımız diğer bazı araştırıcıların sonuçlarını desteklemektedir (Pala, 2016; Sönmez ve Olgun, 2019). Bununla birlikte buğdayda ekim sıklığının 1000 tane ağırlığı üzerine etkisinin olmadığını bildiren araştırma sonuçları da mevcuttur (Arısoy ve ark., 2005; Kazan ve Doğan, 2005; Ulucan ve Atak, 2020). Ekim sıklığındaki artışa bağlı olarak 1000 tane ağırlığının azalması, birim alandaki artan birey sayısına bağlı olarak ışık, su ve besin maddesi için artan rekabetin bir sonucu olarak ortaya çıkar. Dolayısıyla mevcut koşullarda artan birey sayısının her birisi için yeterli miktarda kaynağın bulunduğu koşullarda bitki sıklığının 1000 tane ağırlığı üzerindeki etkisi de önemsiz olacaktır. Bununla birlikte genotiplerin 1000 tane ağırlığı bakımından bitki sıklıklarına tepkisinin farklı olması bitki sıklığı $\times$ genotip interaksiyonunun önemli olmasına neden olmuştur (Çizelge 3 ve Şekil 4).

Şekil 4'de izlendiği gibi, Karakılçık, Fırat-93 ve Massacio genotiplerinde artan sıklıklara bağlı olarak 1000 tane ağırlığında sürekli bir azalma eğilimi gözlenirken, Havrani genotipinin 1000 tane ağılığı hafif bir artışın ardından önemli bir düşüş göstermiştir. Fransız genotipi ise benzer bir eğilim göstermiş olmakla birlikte bu değişim önemsiz olmuştur. Gediz-75 genotipinde ise 1000 tane ağırlığ sıklığın metrekarede 550 tohuma çıkmasıyla önemli derece azalmış, daha sonra artan sıklıkta ise bir değişim göstermemiştir. Bu durum genotiplerin kaynak kullanma yeteneklerindeki farklılığın ve değişen koşullardaki rekabet yeteneklerinin bir yansımasıdır (Haynes, 1980).

Deneme faktörlerinin hektolitre ağırlığı üzerine etkisi istatistiksel olarak önemli bulunmuştur (Çizelge 4). Araştırmada kullanılan çeşitler arasında Havrani, $79.8 \mathrm{~kg}$ ile en yüksek hektolitre ağırlığına sahip genotip olarak belirlenirken, Fırat-93 ve Gediz-75 genotipleri onu takip etmiştir. En düşük hektolitre ağırlığının belirlendiği Massacio çeşidi diğer genotiplerin tümünden istatistiksel olarak düşük hektolitre ağırlığı değerine sahip olmuştur. Genel olarak bakıldığında makarnalık genotiplerin hektolitre ağırlığının ekmeklik genotiplerden daha yüksek olduğu söylenebilir. Akgün ve ark. (2011) yürüttükleri çalışmada hektolitre ağırlığının ekmeklik genotiplerde 71.28 ile $77.35 \mathrm{~kg}$ arasında, makarnalık genotiplerde ise 77.13 ile $79.23 \mathrm{~kg}$ arasında değiştiğini bildirmişlerdir. 
Çizelge 4. Araştırmada iki yıllık ortalama olarak belirlenen 1000 tane ağırlığı, hektolitre ağırlığı, protein oranı, glüten oranı ve tane verimi değerlerinin genotip ve ekim sıklığına bağlı değişimi ve önem seviyeleri

Table 4. Variation and significance levels of 1000 grain weight, test weight, protein ratio, gluten ratio and grain yield values determined as two-year average in the study depending on genotype and planting frequency

\begin{tabular}{|c|c|c|c|c|c|}
\hline & $\begin{array}{l}1000 \text { Tane } \\
\text { Ağırlığı (g) }\end{array}$ & $\begin{array}{l}\text { Hektolitre } \\
\text { Ağırlığı (kg) }\end{array}$ & $\begin{array}{c}\text { Protein Oranı } \\
(\%)\end{array}$ & $\begin{array}{c}\text { Kuru Gluten } \\
\text { Oranı (\%) }\end{array}$ & $\begin{array}{c}\text { Tane Verimi } \\
\left(\mathrm{kg} \mathrm{da}^{-1}\right)\end{array}$ \\
\hline \multicolumn{6}{|l|}{ Genotipler } \\
\hline Karakılçık & $38.6 \mathrm{e}^{+}$ & $77.2 \mathrm{c}$ & $15.0 \mathrm{a}$ & $12.6 \mathrm{a}$ & $513.4 \mathrm{~cd}$ \\
\hline Firat-93 & $49.4 \mathrm{a}$ & $79.1 \mathrm{~b}$ & $13.2 \mathrm{c}$ & $11.1 \mathrm{c}$ & $593.9 \mathrm{~b}$ \\
\hline Gediz-75 & $45.3 \mathrm{~b}$ & $78.7 \mathrm{~b}$ & $13.3 \mathrm{c}$ & $11.3 \mathrm{c}$ & $637.0 \mathrm{a}$ \\
\hline Havrani & $50.6 \mathrm{a}$ & $79.8 \mathrm{a}$ & $14.0 \mathrm{~b}$ & $12.0 \mathrm{~b}$ & $532.2 \mathrm{c}$ \\
\hline Fransız & $42.3 \mathrm{c}$ & $76.2 \mathrm{~d}$ & $15.1 \mathrm{a}$ & $12.9 \mathrm{a}$ & $491.3 \mathrm{~d}$ \\
\hline Massacio & $40.7 d$ & $75.4 \mathrm{e}$ & $11.2 \mathrm{~d}$ & $9.8 \mathrm{~d}$ & $593.1 \mathrm{~b}$ \\
\hline Önem seviyesi (G) & $* *$ & $* *$ & $* *$ & $* *$ & $* *$ \\
\hline \multicolumn{6}{|c|}{ Ekim Sıklıkları (tohum $\mathrm{m}^{-2}$ ) } \\
\hline 450 & 45.9 a & $78.2 \mathrm{a}$ & 13.8 & 11.8 & 566.9 \\
\hline 550 & $44.8 \mathrm{a}$ & $78.0 \mathrm{a}$ & 13.5 & 11.6 & 548.2 \\
\hline 650 & $42.8 \mathrm{~b}$ & $76.9 \mathrm{~b}$ & 13.6 & 11.5 & 565.4 \\
\hline Önem seviyesi (ES) & $* *$ & $* *$ & ns & ns & ns \\
\hline Önem seviyesi $(E S \times G)$ & $* *$ & $* *$ & ns & ns & $* *$ \\
\hline
\end{tabular}

+) Aynı sütunda farklı harflerle gösterilen faktör ortalamaları birbirinden farklıdır $(\mathrm{P}<0.05)$;

*: \%5 hata sınırları içerisinde önemli; **: \%1 hata sınırları içerisinde önemli; ns: önemsiz.

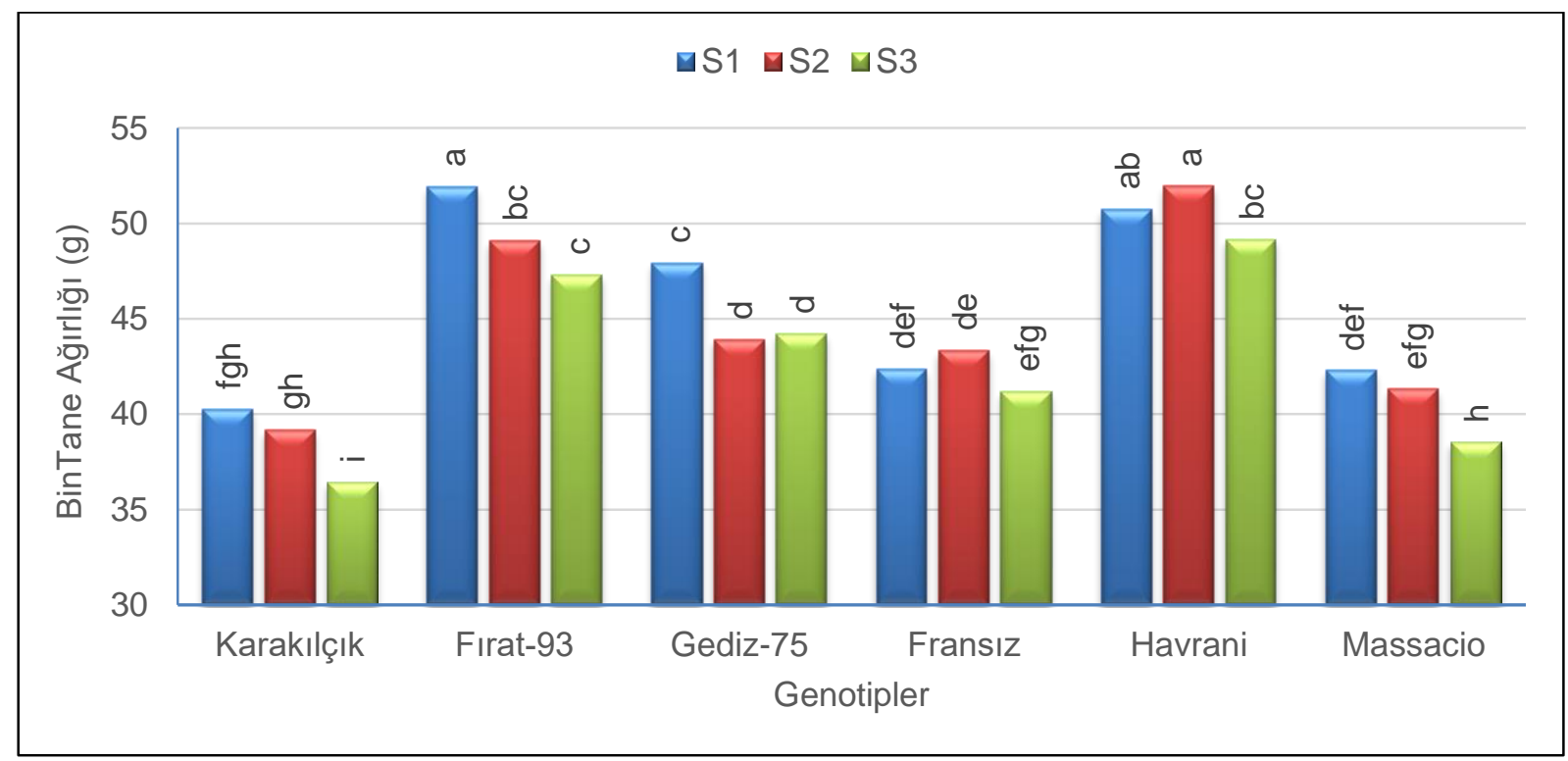

Şekil 4. 1000 tane ağırlığının ekim sıklığı $\times$ genotip interaksiyonuna bağlı olarak değişimi

Figure 4. Variation of thousand grain weight depending on sowing frequency $\times$ genotype interaction

Araştırıcıların bulguları bizim sonuçlarımızı destekler niteliktedir. Aydoğan ve ark. (2004) ise farklı ekmeklik ve makarnalık buğday genotiplerini inceledikleri çalışmada ekmeklik genotipler için ortalama hektolitre ağırlığını $77.1 \mathrm{~kg}$ olarak bildirirken makarnalık genotipler için 77.2 kg olarak bildirmişlerdir. Araştırmalarda kullanılan çeşit sayısı, ekolojik koşullar ve genotiplerin özellikleri hektolitre ağırlıklarını değiştirebilmektedir (Aydoğan ve ark., 2004; Sakin ve ark., 2004). Ekim sıklığının 650 tohum m-2' ye çıkması hektolitre ağırlığında önemli bir azalmaya neden olmuştur. 450 ve 550 tohum $\mathrm{m}^{-2}$ sıklıklarında belirlenen hektolitre ağırlıkları ise birbirinden farksız olmuştur (Çizelge 4). Bulgularımızın aksine, diğer bazı araştırmalarda bitki sıklıklarının hektolitre ağırlığı üzerine etkisi önemsiz olduğu bildirilmiştir (Çekiç ve ark., 2008; Sönmez ve Olgun, 2019). Bu durum ekolojik koşulların farklılığı yanında kullanılan genotiplerin bitki sıklıklarına gösterdikleri tepkinin farklı olması olarak yorumlanabilir.

Hektolitre ağırlığı üzerine bitki sıklığı $\times$ genotip interaksiyonunun etkisi önemli bulunmuştur (Çizelge 4). Makarnalık genotiplerde (Karakılçık, Fırat-93, Gediz-75 
ve Havrani) genel olarak artan bitki sıklıklarında azalma eğilimi gözlenirken, ekmeklik genotiplerden Fransız genotipinde önce önemli bir artış ardından tekrar bir düşüş belirlenmiştir. Massacio genotipinin hektolitre ağırlığı ise bitki sıklıklarına bağlı olarak önemli bir değişim göstermemiştir (Şekil 5). Bununla birlikte tüm sıklıklarda makarnalık genotiplerin daha yüksek hektolitre ağırlığına sahip olduğu görülmektedir. Tüm uygulamalar içerisinde 450 tohum $\mathrm{m}^{-2}$ sıklıkta ekilen FIrat-93 genotipinde belirlenen değer en yüksek değer olurken, bu değer Havrani genotipi için 450 ve 550 tohum $\mathrm{m}^{-2}$ ekim sıklıklarında belirlenen değerden istatistiksel olarak farklı olmuştur. Tanenin şekli, yoğunluğu, büyüklüğü ve homojenliği buğday genotiplerin hektolitre ağırlı̆̆ı üzerinde etkili başlıca faktörlerdir (Sakin ve ark., 2004). Bu özellikleri değiştiren etmenlerin hektolitre ağırlığını etkilemesi muhtemeldir. Genotip özellikleri yanında genotiplerin farklı sıklıklarda doğal kaynaklardan yararlanma yetenekleri ve tane doldurma özellikleri hektolitre ağırlıklarının değişiminde etkili olmuştur. Hektolitre ağırlığının en az $72 \mathrm{~kg}$ olması istenir, (Diepenbrock ve ark., 2005). Kullanılan genotip ve sıklıklar için belirlenen hektolitre ağırlığı değerleri bu değerin üzerindedir.

Protein oranı çeşitler arasında önemli derecede değişim gösterirken, ekim sıklıklarına ve bitki sıklığı $\times$ genotip interaksiyonuna bağlı olarak önemli bir değişim göstermemiştir (Çizelge 4). Fransız ve Karakılçık genotipleri diğerlerinden daha yüksek protein oranına (sırasıyla, \%15.1 ve \%15.0) sahip genotipler olurken, onları Havrani genotipi (\%14.0) takip etmiştir. Bunları birbiri ile yakın protein oranları ile Gediz-75 ve Fırat-93 genotipleri takip etmiştir. Tüm genotipler içerisinde Massacio diğerlerine göre önemli derecede düşük protein oranına sahip genotip olmuştur. Mevcut sonuçlar hem ekmeklik hem de makarnalık buğdaylar için yerel popülasyonların protein oranlarının daha yüksek olduğuna işaret etmektedir. Kendal ve ark. (2012) makarnalık buğday genotiplerinde protein oranının \%10.3 ile 13.1 arasında değiştiğini bildirirken, ekmeklik buğday için Özen ve Akman (2015) protein oranının \%7.5 ile \%12.9 arasında, Sönmez ve Olgun (2019) ise \%9.90 ile \%15.74 arasında değiştiğini bildirmişlerdir. Bu araştırmada belirlenen değerler bu çalışmalarla uyumludur. Protein oranları bitki sıklıklarına bağı olarak önemli bir değişim göstermemiştir. Bu yöndeki bulgularımız Çekiç ve ark. (2008) ve Sönmez ve Olgun (2019)'un bulguları ile uyumludur.

Kuru gluten oranı değerleri geneotiplere bağlı olarak önemli derecede değişirken, ekim sıklıkları ve interaksiyon etkileri istatistiksel olarak önemsiz bulunmuştur. Karakılçık ve Fransız genotiplerinin glüten oranı diğer genoiplere göre önemli derecede yüksek bulunmuştur. Bu iki çeşidi Havrani izlemiştir. En düşük glüten oranı değeri ise Massacio genotipinde tespit edilmiştir. Genel olarak yerel köy çeşitlerinde kuru gluten oranı modern çeşitlere göre daha yüksek olduğu söylenebilir (Çizelge 4). Gluten miktarı bakımından genotipler arasında görülen farklılıkların, genotiplerin kalite unsuru bakımından farklı özelliklere sahip olmasından ileri geldiği söylenebilir. Benzer sonuçlar diğer araştırıcılar tarafından da bildirilmiştir (Demir ve ark., 1987; Korkut ve Çıtak, 1992; Ünal ve ark., 1996).

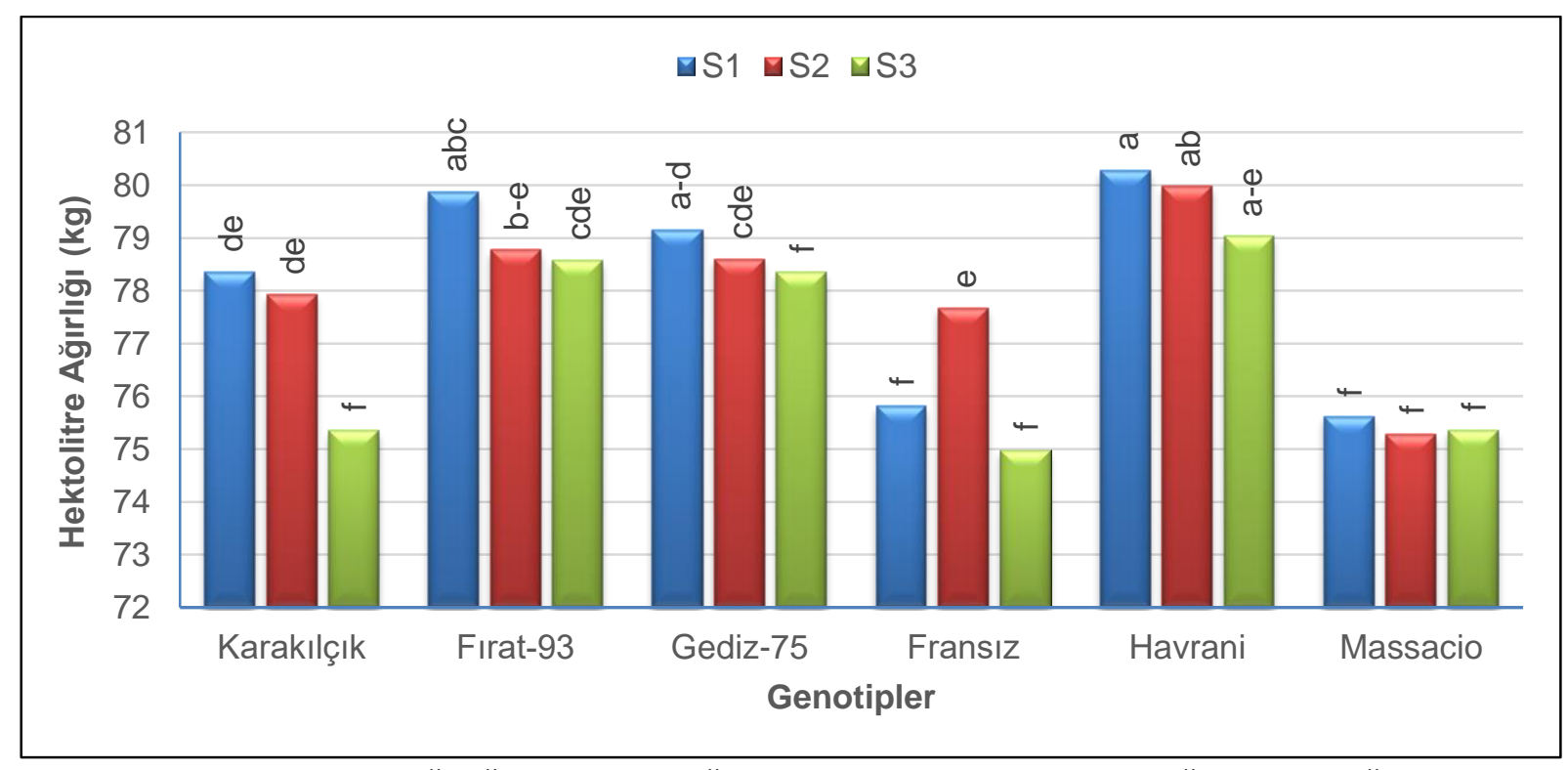

Şekil 5. Hektolitre ağırlığının ekim sıklığı $\times$ genotip interaksiyonuna bağlı olarak değişimi Figure 5. Variation of test weight depending on sowing frequency $\times$ genotype interaction 


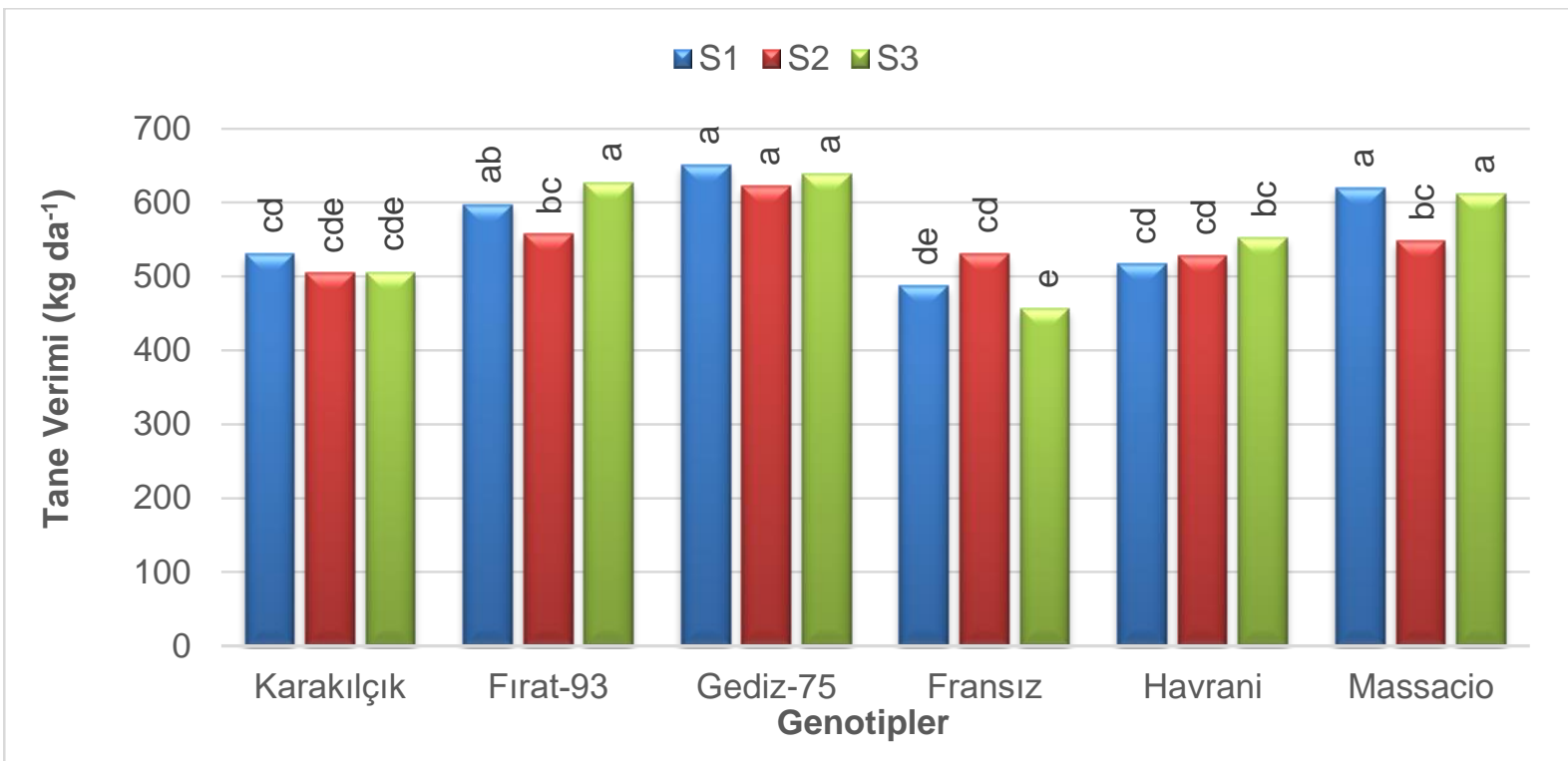

Şekil 6. Tane veriminin ekim sıklığı $\times$ genotip interaksiyonuna bağlı olarak değişimi

Figure 6. Variation of grain yield depending on sowing frequency $\times$ genotype interaction

Ekim sıklıkları için belirlenen glüten içerikleri ise birbirine oldukça yakın olmuştur. Bu yöndeki bulgularımız Ulucan ve Atak (2020) ile uyum içerisindedir.

Tane verimi değerleri genotiplere bağı olarak 491.3 ile $637.0 \mathrm{~kg} \mathrm{da}{ }^{-1}$ arasında değişmiştir. Çeşitlerin ortalama tane verimi değerleri arasındaki bu değişim istatistiksel olarak önemli bulunmuştur (Çizelge 4). Gediz-75 genotipi $637.0 \mathrm{~kg} \mathrm{da}^{-1}$ ile en yüksek verimin elde edildiği genotip olmuştur. Gedi-75'i birbirine oldukça yakın verim değerlerine sahip olan Firat-93 (593.9 $\left.\mathrm{kg} \mathrm{da}^{-1}\right)$ ve Massacio (593.1 $\mathrm{kg} \mathrm{da}^{-1}$ ) genotipleri izlemiştir. En düşük tane verimi değeri ise Fransız genotipinde $\left(491.3 \mathrm{~kg} \mathrm{da}^{-1}\right)$ belirlenmiştir. Benzer ekolojide yürütülen araştırmalarda buğday genotiplerinin verimlerinin önemli farklılıklar gösterdiği bildirilmiştir (Güçlü ve Atak, 2015; Ulucan ve Atak, 2020). Ulucan ve Atak (2020), belirlediğimiz tane verimi değerlerine yakın değerler belirlerken, Güçlü ve Atak (2015) tarafından bildirilen tane verimi değerleri bizim değerlerimizden düşüktür. Bu durum kullanılan genotiplerin farklı olması yanında, benzer bölgede de olsa iklim koşullarında, özellikle gelişme dönemindeki yağış ve sıcaklık, meydana gelen ekstrem farklılıklardan kaynaklanabilir. Ekim sıklıklarına bağlı olarak tane verimleri 548.2 ile $566.9 \mathrm{~kg} \mathrm{da}^{-1}$ arasında değişmiş, bu değişim istatistiksel olarak önemli bulunmamıştır (Çizelge 4). Genotiplerin değişen bitki sıklıklarına tane verimi açısından tepkisinin farklı olması bitki sıklı̆̆ı $x$ genotip interaksiyonunun önemli çıkmasına neden olmuştur (Çizelge 4 ve Şekil 6).

Şekil 6'da izlendiği gibi genotipler değişen bitki sıklıklarında tane verimi değerleri açısından farklı eğilimler göstermişlerdir. Karakılçık, Gediz-75 ve Havrani genotipleri ekim sıklığındaki değişimden önemli derecede etkilenmemiş ve 3 ekim sıklığında da benzer tane verimi değerlerine ulaşılmıştır. Fırat-93 ve Massacio genotiplerinde 550 tohum $\mathrm{m}^{-2}$ sıklığında 650 tohum m $\mathrm{m}^{-2}$ sıklığına göre önemli derecede düşük tane verimleri elde edilirken, Fransız genotipinde 550 tohum $\mathrm{m}^{-2}$ sıklığında 650 tohum $\mathrm{m}^{-2}$ sıklığına göre önemli derecede yüksek tane verimleri elde edilmiştir. Tüm bitki sıklıkları için Gediz-75, Massacio ve Fırat-93 yüksek verimli genotipler olarak dikkati çekmiştir. Tane verimi bakımından genotiplerin değişen ekim sıklıklarına tepkisinin farklı olabileceği diğer araştırıcılar tarafından da bildirilmiştir (Geleta ve ark., 2002; Ulucan ve Atak, 2020).

Sonuç olarak, Hatay ekolojik koşullarında yürütülen bu çalışmada farklı ekim sıklıklarında $(450,550$ ve 650 adet $\mathrm{m}^{-2}$ ) bazı buğday genotiplerinin (Fransız, Havrani, Karakılçık, Fırat-93, Gediz-75 ve Masaccio) verim ve bazı kalite yönünden performansları test edilmiştir. Ekim sıklıklarının başaklanma süresi, başakta tane sayısı, bin tane ağırlığı ve hektolitre ağırlığı yönünden istatistiki olarak önemli olduğu saptanmıştır. Genotipler, incelenen tüm özellikler yönünden istatistiki olarak önemli bulunmuştur. Ekim sıklığı x genotip interaksiyonu ise başaklanma süresi, başakta tane ağırlığı, bin tane ağırlığı, hektolitre ağırlığı ve tane verimi yönüyle önemli olmuştur. Genotipler yönünden tane verimleri $491.3 \mathrm{~kg}$ $\mathrm{da}^{-1}$ (Fransız) -637.0 (Gediz-75) $\mathrm{kg} \mathrm{da}^{-1}$ arasında değişim göstermiştir. Sonuçlarımıza göre Gediz-75 ve Massacio çeşitlerinde 450 ve 650 tohum $\mathrm{m}^{2}$ ekim sıklıklarında tane veriminin $650 \mathrm{~kg} \mathrm{da}^{-1}$ seviyelerine ulaşabildiği belirlenmiştir. Bununla birlikte, genotiplerin değişen ekim sıklıklarında farklı tepkiler göstermesi, ekim 
sıklığının genotiplere göre ayarlanması gerektiğini göstermektedir. Köy çeşitlerinin verimlerinin modern çeşitlere göre daha düşük olsa da kalite özelikleri yönüyle aynı veya daha üstün değerlere sahip olduğunu söylenebilir.

\section{ÖZET}

Amaç: $\mathrm{Bu}$ araştırma, ekim sıklığının buğday genotiplerinde verim ve bazı kalite özelliklerine etkisini belirlemek amacıyla Hatay ekolojik koşullarında yürütülmüştür. Denemede, altı adet buğday genotipi (Fırat-93, Fransız, Gediz-75, Havrani, Karakılçık ve Masaccio) ve üç ekim sıklığı $\left(450,550\right.$ ve 650 tohum m $\left.^{-2}\right)$ kullanılarak test edilmiştir.

Yöntem ve Bulgular: Denemeler, Tesadüf Blokları Bölünmüş Parseller Deneme Deseninde 3 tekerrürlü olarak kurulmuş olup, ana parsellere ekim sıklıkları ve alt parsellere ise genotipler yerleştirilmiştir. Araştırmada; başaklanma süresi, bitki boyu, başak uzunluğu, başakta tane sayısı, başak tane ağırlığı, tane verimi, bin tane ağırlığı, hektolitre ağırlığı, protein oranı ve kuru gluten oranı özellikleri incelenmiştir.

Genel Yorum: iki yıllık ortalama değerlere göre; başaklanma süresi, başakta tane sayısı, bin tane ağırlığı ve hektolitre ağırlığı yönünden ekim sıkıkları arasındaki farklılıklar önemli bulunmuştur. Genotipler, incelenen tüm özellikler yönüyle önemli çıkmıştır. Ekim sıklığı $x$ genotip interaksiyonu ise başaklanma süresi, başakta tane ağırlığı, bin tane ağırlığı, hektolitre ağırlığı ve tane verimi için önemli olmuştur. Genotipler yönünden tane verimleri $491.3 \mathrm{~kg}^{-1}$ (Fransız) - 637.0 (Gediz-75) $\mathrm{kg}^{-1}$ arasında değişim göstermiştir.

Çalışmanın Önemi ve Etkisi: Sonuçlar, ekim sıklığının buğday genotiplerinde verim ve kalite üzerine genotiplere göre değişen oranlarda etkili bir kültürel faktör olduğunu ortaya çıkarmıştır. Köy (yerel) çeşitlerinin verimlerinin modern çeşitlere göre daha düşük olsa da kalite özelikleri yönüyle aynı veya daha üstün değerlere sahip olduğu belirlenmiştir. Bu nedenle yerel çeşitler korunmalı ve yetiştirme teknikleriyle ilgili çalışmalar devam ettirilmelidir.

Anahtar Kelimeler: Buğday, köy çeşitleri, ekim sıkılığı, verim ve kalite.

\section{ÇIKAR ÇATIŞMA BEYANI}

Yazarlar çalışma konusunda çıkar çatışmasının olmadığını beyan eder.

\section{ARAŞTIRMACILARIN KATKI ORANI BEYANI}

Yazarlar çalışmaya eşit oranda katkı sağlamış olduklarını beyan eder.

\section{KAYNAKLAR}

Akgün I, Tosun M, Sağsöz S (1997) Erzurum ekolojik bazı koşullarında bazı tritikale hat ve çeşitlerinin verim ve verim unsurları üzerine bir araştırma. Atatürk Üniv. Ziraat Fak. Derg. 28(1): 103-119.

Aktaş B (2010) Kuru koşullar için ıslah edilmiş bazı ekmeklik buğday (Triticum aestivum L.) çeşitlerinin karakterizasyonu. Doktora Tezi, Ankara Üniversitesi Fen Bilimleri Enstitüsü Tarla Bitkileri ABD. $126 \mathrm{~s}$.

Anonim (2016) Türkiye'nin Buğday Atlası, WWF-Türkiye (Doğal Hayatı Koruma Vakfı), İstanbul, Türkiye, Eylül 2016

Anonim (2018) T.C. Tarım ve Orman Bakanlığı Meteoroloji Genel Müdürlüğü. Hatay İl Müdürlüğü

Anonim (2020) www.tuik.gov.tr/ Erişim,. Şubat, 2021.

Anoymous http://www.fao.org/faostat/en/\#data/QC Erişim, Mart, 2021

Arısoy RZ, Kaya Y, Taner A, Çeri S, Gültekin I (2005) Konya koşullarında farklı tohum sıklıklarında ekilen buğday ve tritikalenin verim ve verim unsurlarına etkisi. Türkiye VI. Tarla Bitkileri Kongresi, 5-9 Eylül, Antalya, Cilt I, s: 131-135.

Atak M (2017) Buğday ve Türkiye buğday köy çeşitleri. MKÜ Zir. Fak. Derg. 22(2):71-88.

Atak M, Çiftçi CY (2006) Bazı tritikale çeşit ve hatlarının morfolojik karakterizasyonu. J. Agr. Sci.-Tarım Bili. 12(1): 101-111.

Aydoğan S, Şahin M, Göçmen A, Akçura M (2004) Orta Anadolu'nun değişik ekolojilerinde ekmeklik ve makarnalık buğday çeşitlerinin farklı çevrelerde tane verimi ve bazı kalite özelliklerinin incelenmesi. Bitkisel Araş. Derg. 1: 39-47.

Aydoğan S, Soylu S (2017) Ekmeklik buğday çeşitlerinin verim ve verim öğeleri ile bazı kalite özelliklerinin belirlenmesi. Tarla Bit. Mer. Araş. Ens. Derg. 26(1): 24-30.

Bilgin O, Korkut KZ (2005) Bazı ekmeklik buğday çeşit ve hatlarının ( $T$. aestivum $L$.) tane verimi ve bazı fenolojik özelliklerinin belirlenmesi. T. Üniv. T. Zir. Fak. Derg. 2(1): 58-65.

Çekiç C, Savaşlı E, Dayıoğlu R, Önder O, Karaduman Y, Avcıoğlu R (2008) Ekmeklik buğdayda (Triticum aestivum $\mathrm{L}$.) ekim zamanı ve sıklığı ile kalite kriterleri arasındaki ilişkilerin belirlenmesi. Ülkesel Tahıl Sempozyumu, 2-5 Haziran, Konya, s: 201-209. 
Demir i, Bilgen G, Altınbaş M, Çelik N (1987) Ileri buğday varyetelerinin agronomik ve kalite karakterleri. Türkiye Tahıl Sempozyumu, 6-9 Ekim, Bursa, s: 49-58.

Diepenbrock W, Ellmer F, Léon J (2005) Ackerbau, Pflanzenbau und Pflanzenzüchtung, UTB 2629, Verlag Eugen Ulmer, Stuttgart.

Dinç S, Erekul O (2010) Bazı ekmeklik buğdaylarda (Triticum aestivum L.) ekim sıklığının verim ve verim öğelerine etkisi. Adnan Menderes Üniversitesi Ziraat Fakültesi Dergisi 7(2): 117-125.

Geleta B, Atak M, Baenziger PS, Nelson LA, Baltenesperger DD, Eskridge KM, Shipman MJ, Shelton DR (2002) Seeding rate and genotype effect on agronomic performance and end-use quality of winter wheat. Crop Sci. 42: 827-832.

Gençtan T, Sağlam N (1987) Ekim zamanının ve ekim sıklığının üç ekmeklik buğday çeşidinde verim ve verim unsuruna etkisi. Türkiye Tahıl Sempozyumu, 69 Ekim, Bursa, s:171-183.

Güçlü M, Atak M (2015) Hatay koşullarinda bazi ekmeklik buğday (Triticum aestivum L.) genotiplerinin verim ve kalite özelliklerinin belirlenmesi. Türkiye 11. Tarla Bitkileri Kongresi, 7-10 Eylül, Çanakkale, Cilt I, s: 112116.

Haynes RJ (1980) Competitive aspects of the grasslegume association. Adv. Agron. 33: 227-261.

Jaradat A A (2013) Wheat Landraces: A mini review. Emir. J. Food Agric. 25(1): 20-29.

Karagöz A, Zencirci N (2005) Variation in wheat (Triticum spp.) landraces from different altitudes of three regions of Turkey. Genet. Resour. Crop Ev. 52:6775785.

Kazan T, Doğan R (2005) Pehlivan ekmeklik buğday (Triticum aest. var. aest. L.) çeşidinde ekim zamanı ve ekim sıklığı üzerine araştırma. Uludag Üniv. Ziraat Fak. Derg. 19(1): 63-76.

Kendal E, Tekdal S, Aktaş H, Karaman M (2012) Bazı makarnalık buğday çeşitlerinin Diyarbakır ve Adıyaman sulu koşullarında verim ve kalite parametreleri yönünden karşılaştırılması. Uludag Üniv. Ziraat Fak. Derg. 26(2): 1-14.

Korkut KZ, Çıtak N (1992) Yerli ve yabancı kökenli ekmeklik buğday çeşitlerinde tane verimi ve ekmeklik kalitesi unsurları üzerine araştırmalar. T. Üniv. T. Zir. Fak. Derg. 1(1): 113-121.

Kün E (1996) Tahıllar-ı (Serin Iklim Tahılları). Ankara Üniversitesi Ziraat Fakültesi Yayınları, Yayın No:1451, Ankara.
Menshawy, AMM (2007) Evaluation of some early bread wheat genotypes under different sowing dates: 2 . Agronomic characters. Egypt J. Plant Breed. 11: 4155.

Morgounov A, Keser M, Kan M, Küçükçongar M, Özdemir F, Gummanow N, Muminjanov H, Zuev E, Qualset CO (2016). Wheat landraces currently grown in Turkey: Distribution, diversity and use. Crop Sci. 56: 1-13.

Mut Z, Aydın N, Bayramoğlu HO, Özcan H (2007) Bazı ekmeklik buğday (Triticum aestivum L.) genotiplerinin verim ve başlıca kalite özelliklerinin belirlenmesi. OMÜ Zir. Fak. Derg. 22(2): 193-201.

Özen S, Akman Z (2015) Yozgat ekolojik koşullarında bazı ekmeklik buğday çeşitlerinin verim ve kalite özelliklerinin belirlenmesi. Süleyman Demirel Üniversitesi Ziraat Fakültesi Dergisi 10(1):35-43.

Özer K (1997) MV-20 Ekmeklik buğday (Triticum aestivum var. aestivum L.) çeşidinde farklı ekim sıklığı ve farklı azotlu gübre uygulamalarının verim ve verim öğeleri üzerine etkileri. Yüksek Lisans Tezi, Uludağ Üniversitesi, Fen Bilimleri Enstitüsü Tarla Bitkileri ABD, $78 \mathrm{~s}$.

Pala D (2016) Farklı ekim sıklıklarının iki ekmeklik buğday (Triticum aestivum L.) çeşidinde tane verimi ve bazı verim öğeleri üzerine etkilerinin belirlenmesi. Yüksek Lisans Tezi, Ahi Evran Üniversitesi, Fen Bilimleri. Enstitüsü, Tarla Bitkileri ABD, $64 \mathrm{~s}$.

Sakin MA, Yıldırım A, Gökmen S (2004) Tokat Kazova koşullarında bazı makarnalık buğday genotiplerinin verim, verim unsurları ile kalite özelliklerinin belirlenmesi. J. Agr. Sci.-Tarim Bili. 10(4): 481-489.

Shewry P.R (2009) Wheat. J. Exp. Bot. 60 (6): 1537-1553. Sönmez AC, Olgun M (2019) Ekmeklik buğdayda (Triticum aestivum L.) ekim sıklığının tane iriliği ve bazı kalite parametreleri üzerine etkisinin incelenmesi. Türk Tarım Doğa Bilimleri Dergisi 6(4): 729-736.

Ulucan I, Atak M (2020) Ekim sıklığının ekmeklik buğday çeşitlerinde (Triticum aestivum $\mathrm{L}$.) verim ve bazı kalite özelliklerine etkisi. Yyü. Tar. Bil. Derg. 30(4): 788-800.

Ünal S, Olçay M, Özer Ç (1996) Bazı ekmeklik buğday çeşitlerinin kalite niteliklerinin belirlenmesi. Gıda 21(6): 451-456. 